Golaghat, where the Doyang River meanders through thick jungle country midway between the Naga Hills and the huge Brahmaputra. It had somehow become separated from its mother. News was sent to the manager of the elephant-catching operations, and a koonkie and some men were dispatched to secure it and bring it in. Had it been left alone, it would have fallen an easy prey to the first roaming tiger or leopard. A $3 \mathrm{ft} .2$ in. baby female, she was put on the bottle and soon became quite tame with the Assamese mahouts and trainers in the camp, and was called Sabitri.

The Calcutta and London Zoos were informed and immediately the latter arranged for her travel by air from Assam to England. After a flight which made elephant history, she was rechristened Dumbo on arrival at London ; and it is hoped that this real flying elephant will thrive in her new home and never miss the luscious green jungles of Assam, the place of her birth.

\title{
THE APES OF GIBRALTAR
}

\section{By Sir Claud Russeli, K.C.M.G.}

It is, I think, common knowledge that in the course of the war the defences of Gibraltar were strengthened, the garrison reinforced, and the civilian population largely evacuated. But there was another notable measure taken which, so far as I know, has escaped publicity. It is not easy to come by information on the affairs of Gibraltar, but the local belief is that during a bricf official visit to the Rock, Mr. Churchill became aware that the famous Apes had so decreased in numbers as to make their continued existence precarious. Conscious, no doubt, of our Society's good purpose, and aware, perhaps, of the age-long belief that if ever the Apes should come to an end a like fate would befall our possession of Gibraltar, the Prime Minister gave an urgent order that the Apes should be increased by such a number as would ensure their preservation. This was done by an importation of monkeys of the same species (Macaca sylvana) from Barbary, across the Straits, and these are now, to all appearance, well established in their new home. Their location is about half-way up the Rock, and accessible by road. A soldier of the garrison has charge of 


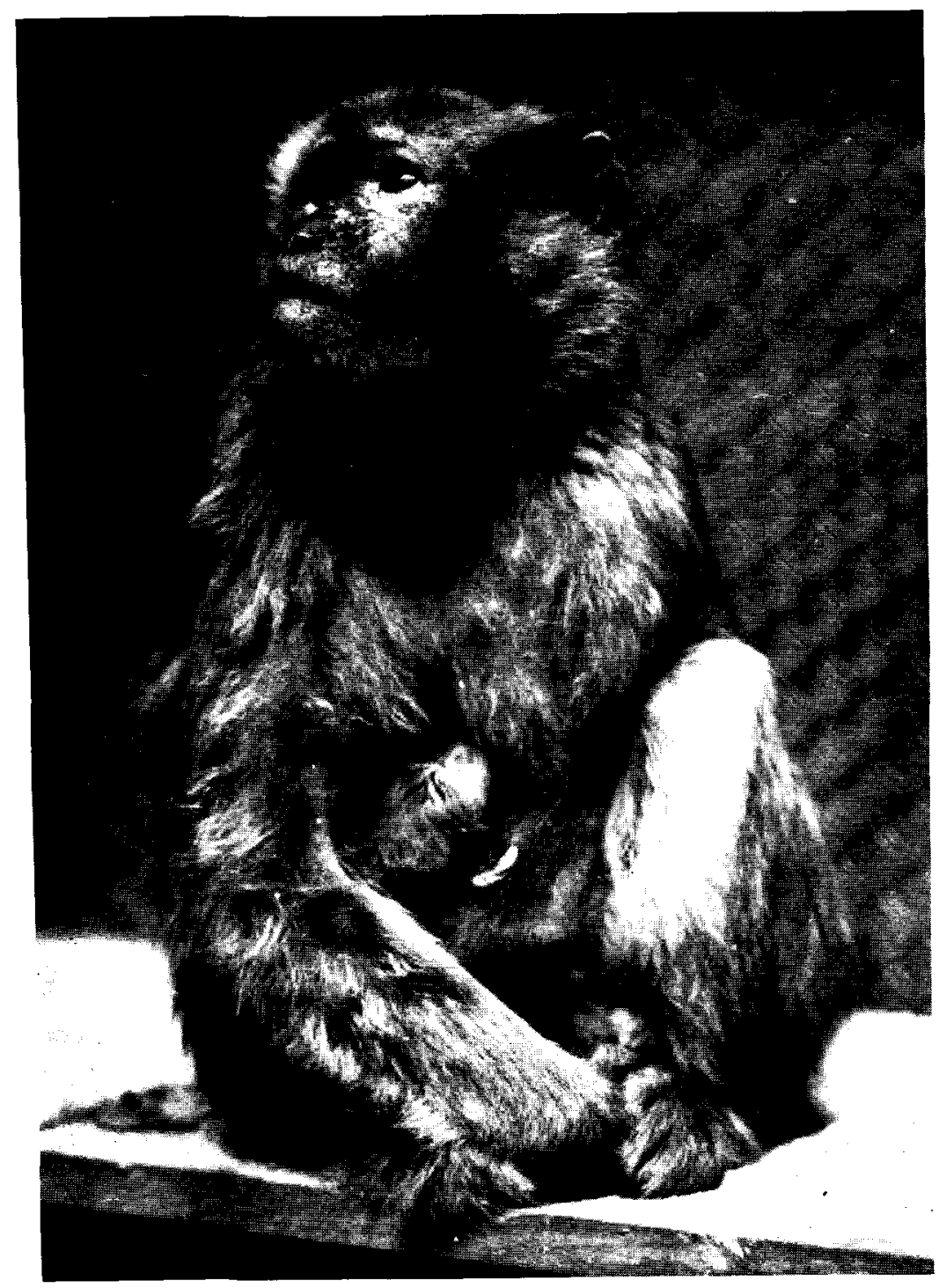

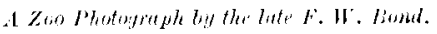

'THE GIBHALITAR OR BARBARY APE. 
them and notice boards here and there request visitors " not to touch or feed the roaming Apes ", but in practice no objection is made if anyone wishes to give them fruit. Judging by the number of young ones, the Apes have multiplied since their arrival and the total colony appears to amount now to about twenty. They do not wander far from their habitat, but occasionally make their way down the hillside to the disused cemetery at the entrance to the town, where they will spend the day in the trees and on the walls, to the great diversion of human passers-by. They are all very tame, and the activity and agility of the young ones is attractive, but the fully grown ones, of which there would seem to be only three or four, are ugly by reason of those characteristics of their species : callosities on the buttocks and the absence of a tail. They are bad-mannered, and will thrust a paw into a man's pocket in search of food or, for the same purpose, snatch a lady's bag and look inside it. It may well be that they are unreliable in temper and if angered might become aggressive.

A remnant of the original Apes is said to survive in a secluded part of the Rock. They have no association with the newcomers and are seldom seen.

The mention of possible aggressiveness recalls an incident in the Apes' history. It was in 1912. One of them attacked a little girl on an unfrequented road. He jumped on her back, pulled off her hat and pulled her hair. The child who was on her way to school, carried some books secured by a strap. Holding the end of the strap, she courageously swung the bundle over her head, repeatedly hitting the ape until he let go and made off. It so happened that there was at that time a man in the garrison-a Sergeant, R.A.--who had made friends with the Apes; he had won their confidence, and it was said that he could do anything with them. Hearing of the matter he was concerned for the good name of his friends, and he submitted, officially and through the proper channel, that it was desirable that such conduct should not go unpunished. The case came to the knowledge of the Governor, Sir Archibald Hunter, who ordered that the Ape be brought before him. At the appointed hour the Sergeant reported at the Convent, and was admitted to the Governor's study. He came in leading his prisoner by the hand. The Ape, who was walking upright, hung his head, and looked ashamed and, as Sir Archibald said afterwards: "One could see he knew perfectly well what he was there for." His Excellency treated the case with judicial gravity, and after a brief hearing (there being no defence) and consultation with the Sergeant, 
he sentenced the accused to ten days' exposure on the hillside in a portable cage. A week later the Sergeant reported that the Ape's conduct in confinement was good; he added that fellow-Apes were feeding him through his prison-bars. The Governor thereupon concluded that the prisoner had earned a remission of his sentence, and ordered his release.

\section{THE 1950 TANGANYIKA GAME BILL}

That the Government of Tanganyika is taking seriously its obligations under the 1933 International Convention for the Protection of African Fauna and Flora, is shown by the draft of the new Game Bill. The explanatory note particularly reflects an appreciation of the value of wild life and a realization that the world to-day is watching with growing concern the depreciation of the fauna of Africa. It will hardly be disputed that the new Bill exceeds in courage and imagination any game preservation legislation previously attempted in the country, and it will be the earnest hope of lovers of nature everywhere, particularly of the members of the Fauna Preservation Society, that the effort meets the success which it deserves.

The new bill introduces a very unusual system of game licences. Instead of the ramifications of visitors, residents, major and minor game licences, all hunters are put on the same footing. According to what they wish to shoot so they pay, in advance, with a minimum of $£ 1$ for a licence. There is, of course, a maximum number of any kind of animal which may be "bought" in any one year. For example permission to shoot one Giraffe only may be bought and it costs $£ 15$, whereas up to eight Impala may be shot annually at a cost of $2 s$. each.

It will be interesting and instructive to see how this system of game $\grave{a}$ la carte works out in practice. What is very important is that it puts the African on the same basis as other races. Under previous legislation he was allowed to kill almost unrestrictedly " to feed himself and his dependents". That the indigenous race should live on the country as it had always done seemed no doubt an excellent and fair provision; in practice it made killing, including killing for profit, uncontrollable and resulted in the decimation of the larger wild life of the country. To put all races on the same footing is a bold step but an essential one. 